\title{
Examining the Effects of Netropsin on the Curvature of DNA A-Tracts Using Electrophoresis
}

\author{
Jillian Miller and Justin P. Peters *(D) \\ Department of Chemistry and Biochemistry, University of Northern Iowa, 1227 West 27th Street, \\ Cedar Falls, IA 50614, USA \\ * Correspondence: justin.peters@uni.edu
}

\begin{abstract}
A-tracts are sequences of repeated adenine bases that, under the proper conditions, are capable of mediating DNA curvature. A-tracts occur naturally in the regulatory regions of many organisms, yet their biological functions are not fully understood. Orienting multiple A-tracts together constructively or destructively in a phase has the potential to create different shapes in the DNA helix axis. One means of detecting these molecular shape differences is from altered DNA mobilities measured using electrophoresis. The small molecule netropsin binds the minor groove of DNA, particularly at AT-rich sequences including A-tracts. Here, we systematically test the hypothesis that netropsin binding eliminates the curvature of A-tracts by measuring the electrophoretic mobilities of seven 98-base pair DNA samples containing different numbers and arrangements of centrally located A-tracts under varying conditions with netropsin. We find that netropsin binding eliminates the mobility difference between the DNA fragments with different A-tract arrangements in a concentration-dependent manner. This work provides evidence for the straightening of A-tracts upon netropsin binding and illustrates an artificial approach to re-sculpt DNA shape.
\end{abstract}

Citation: Miller, J.; Peters, J.P.

Examining the Effects of Netropsin on the Curvature of DNA A-Tracts Using Electrophoresis. Molecules 2021, 26, 5871. https://doi.org/10.3390/ molecules26195871

Academic Editor: Marijana Radić Stojković

Received: 2 August 2021

Accepted: 23 September 2021

Published: 28 September 2021

Publisher's Note: MDPI stays neutral with regard to jurisdictional claims in published maps and institutional affiliations.

Keywords: A-tract curvature; DNA shape; electrophoresis; netropsin

\section{Introduction}

The sequence-directed curvature of DNA A-tracts in vitro has long been appreciated, yet the biological function of A-tracts in vivo is not fully understood. Macroscopically curved DNA sequences have reduced electrophoretic mobility compared to straight molecules of the same length in polyacrylamide gels [1-4], even after extrapolation to zero polyacrylamide concentration [5]. Curved DNA molecules were also shown to migrate anomalously slow in free solution [6,7]. Early studies showed that a continuous run of adenine $(\mathrm{dA})$ residues is required for curvature, that the constructive phasing of consecutive A-tracts is needed for an additive effect, and that the number of $\mathrm{dA}$ residues is important [8]. Cyclization kinetics experiments with theoretical modeling and computer simulations have determined that $\mathrm{A}_{6}$-tracts result in an overall curvature of the DNA helix by $17-21$ degrees [9].

The initial observation that A-tracts are straight in crystal structures [10,11] prompted molecular dynamics simulations of A-tracts [12-14] and NMR solution structures [15,16], which showed that A-tracts are curved under appropriate solution conditions. Temperature, divalent metal cations, and concentrated monovalent cations have been shown to be important mediators of curvature as well [17-20]. The degree of the A-tract curvature is also influenced by monovalent cation identity, an effect thought to arise from differential van der Waals radii [21]. The probing of A.T base pair opening kinetics as a function of ammonium cation suggests that the unique A-tract conformation is favored at a lower cation concentration [22].

Chemical modifications also have the ability to modulate curvature; e.g., pyrimidine 5-methyl groups were shown to have a significant effect on the degree of curvature, with a 
conversion from $\mathrm{A}_{4} \mathrm{~T}_{4}$ to the unmethylated counterpart $\mathrm{A}_{4} \mathrm{U}_{4}$ associated with an increase in curvature $[23,24]$. The mechanism proposed was that methyl groups are modulating the width of the major groove. This further led to a model where sequence-dependent stacking interactions drive the A-tract base pairs into a conformation where the minor groove is narrowed [25]. Bases that prevent this reduction in minor groove width were hypothesized to result in a reduced curvature, e.g., the 2-amino group of guanine or 2 -aminoadenine [26,27]. An alternative, electrostatic model argues that a narrow minor groove is the result of the localization of cations and ordered water molecules that form a "spine of hydration" [28-33] and that purine 2-amino groups act to disrupt this hydration spine [34]. Similarly, it was argued that the unique hydration pattern, and consequent curvature of DNA A-tracts, can be disrupted by elevating the temperature or adding dehydrating agents [35]. It was also shown that organic cosolvents and dehydrating agents used in crystallization, e.g., 2-methyl-2,4-pentanediol (MPD), decrease the gel mobility anomaly [36-38], as well as the rate of cyclization of DNAs that are curved due to phased A-tracts $[39,40]$.

The influence of the flanking DNA sequence has been explored, with changes in flanking residues at most affecting the total curvature by $10-15 \%$. The greatest degree of curvature occurred when the A-tract was flanked by $\mathrm{dC}$ on the $5^{\prime}$ side and $\mathrm{dT}$ on the $3^{\prime}$ side [41]. High resolution chemical probing revealed that the minor groove of A-tracts progressively narrows from $5^{\prime} \rightarrow 3^{\prime}$ along the $\mathrm{dA}$ strand [42]. The surprising result that $\mathrm{A}_{4} \mathrm{~T}_{4}$ is curved whereas $\mathrm{T}_{4} \mathrm{~A}_{4}$ is not led to "junction" and "wedge" models that neglect thermal fluctuations and deal with static parameters of the DNA base steps $[43,44]$. It was found that TpA steps, as opposed to ApT steps, have a significantly different local curvature, and that their positioning at the edge of the A-tracts results in an altered global curvature $[21,45,46]$. This result was confirmed by the differential chemical susceptibility of $\mathrm{A}_{4} \mathrm{~T}_{4}$ versus $\mathrm{T}_{4} \mathrm{~A}_{4}$ [47].

Evidence that cations bind in the A-tract minor groove $[48,49]$ led to the model of DNA grooves as flexible ionophores that adjust in width in response to cation coordination [50,51]. This model is consistent with the observations that the site-binding of divalent cations, such as $\mathrm{Mg}^{2+}$, bridge close phosphate groups, thereby promoting A-tract curvature $[52,53]$. This model suggests that groove occupancy by site-bound cations determines the observed behavior of A-tract, G-tract, and generic DNA sequences [54,55]. Further studies have shown that monovalent cation binding to the A-tract minor groove likely occurs at most one-third of the time $[56,57]$, and that excess monovalent cation binding to the A-tract minor groove is not the cause of the unique A-tract conformation [20]. These latter studies propose that monovalent cations may be linked to a conformation transition (from B-DNA to so-called $\mathrm{B}^{*}$-DNA or $\mathrm{B}^{\prime}$-DNA) with the formation of a narrow minor groove, and that specific protein contacts can drive generic DNA sequences into this conformation [58,59].

Antibiotic drugs, such as netropsin, $[60,61]$ preferentially bind at the location of a narrow minor groove of DNA, such as A-tracts, [62-64] and directly or indirectly impact the curvature [65]. Netropsin has been shown to form two distinct complexes with the A/T binding sites [66,67], presumably resulting from an equilibrium between the two conformations of the minor groove [68,69]. Flanking bases and cosolutes (such as betaine and MPD) also influence the conformation of the minor groove binding site [70].

Experimentally, we hypothesize that antibiotic drugs with an affinity for A/T sequences, such as netropsin, can straighten DNA A-tracts by binding in the A-tract minor groove. This hypothesis is explored in this work by systematically comparing DNA constructs with in-phase and out-of-phase A-tracts using both gel and capillary electrophoresis. Although polyacrylamide gel electrophoresis (PAGE) is commonly thought to be the most sensitive indicator of DNA curvature, in this work, we demonstrate that very similar mobility differences of the DNA constructs are also observed with capillary electrophoresis (CE). Hence, the A-tract-containing samples exhibit a similar degree of curvature in free solution and in polyacrylamide gels. 


\section{Results and Discussion}

Sequences for the 98-bp DNA constructs used in this work are shown in Figure 1A. A-tracts are considered "in-phase" when spaced by an even multiple of the DNA helical repeat, so that the A-tracts all occupy the same face of the DNA double helix and the curvature of the individual A-tracts is additive. Fragments $0,1,2 i, 3 i$, and $4 i$ contain the indicated number of in-phase $\mathrm{A}_{6}$-tracts. A-tracts can also be spaced by half multiples of the helical repeat, placing them "out-of-phase" on opposite faces of the DNA double helix. Sample 2i/o (in/out) contains two sets of in-phase $A_{6}$-tracts with 15 residues between the first set and second set, making the two pairs out-of-phase with each other. Sample 40 contains four out-of-phase $\mathrm{A}_{6}$-tracts. Figure $1 \mathrm{~B}$ provides a visual representation of the shapes of the DNA constructs imagined in this work.

\section{A \\ 0 \\ $3 \mathbf{i}$ \\ 2i/o AGCCTAGCCT

AGCCTAGCCT ATGACATGAC ACGTTACGAC CAGACCAGCT GCACTGCAGA CTGGGCCGAA AAAAGCTGAC TGTACTGTAT GCAATGCAAC CTCACCTC TCGGATCGGA TACTGTACTG TGCAATGCTG GTCTGGTCGA CGTGACGTCT GACCCGGCTT TTTTCGACTG ACATGACATA CGTTACGTTG GAGTGGAG

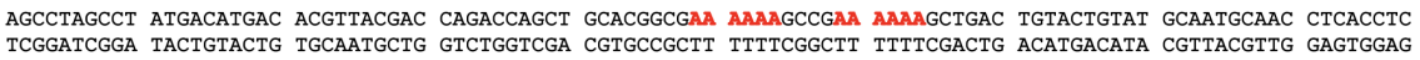
AGCCTAGCCT ATGACATGAC ACGTTACGAC CAGAGCGCAA AAAAGGCGAA AAAAGCCGAA AAAAGCTGAC TGTACTGTAT GCAATGCAAC CTCACCTC TCGGATCGGA TACTGTACTG TGCAATGCTG GTCTCGCGTT TTTTCCGCTT TTTTCGGCTT TTTTCGACTG ACATGACATA CGTTACGTTG GAGTGGAG AGCCTAGCCT ATGACATGAC ACGTTACGAA AAAAGCGCAA AAAAGGCGAA AAAAGCCGAA AAAAGCTGAC TGTACTGTAT GCAATGCAAC CTCACCTC TCGGATCGGA TACTGTACTG TGCAATGCTT TTTTCGCGTT TTTTCCGCTT TTTTCGGCTT TTTTCGACTG ACATGACATA CGTTACGTTG GAGTGGAG
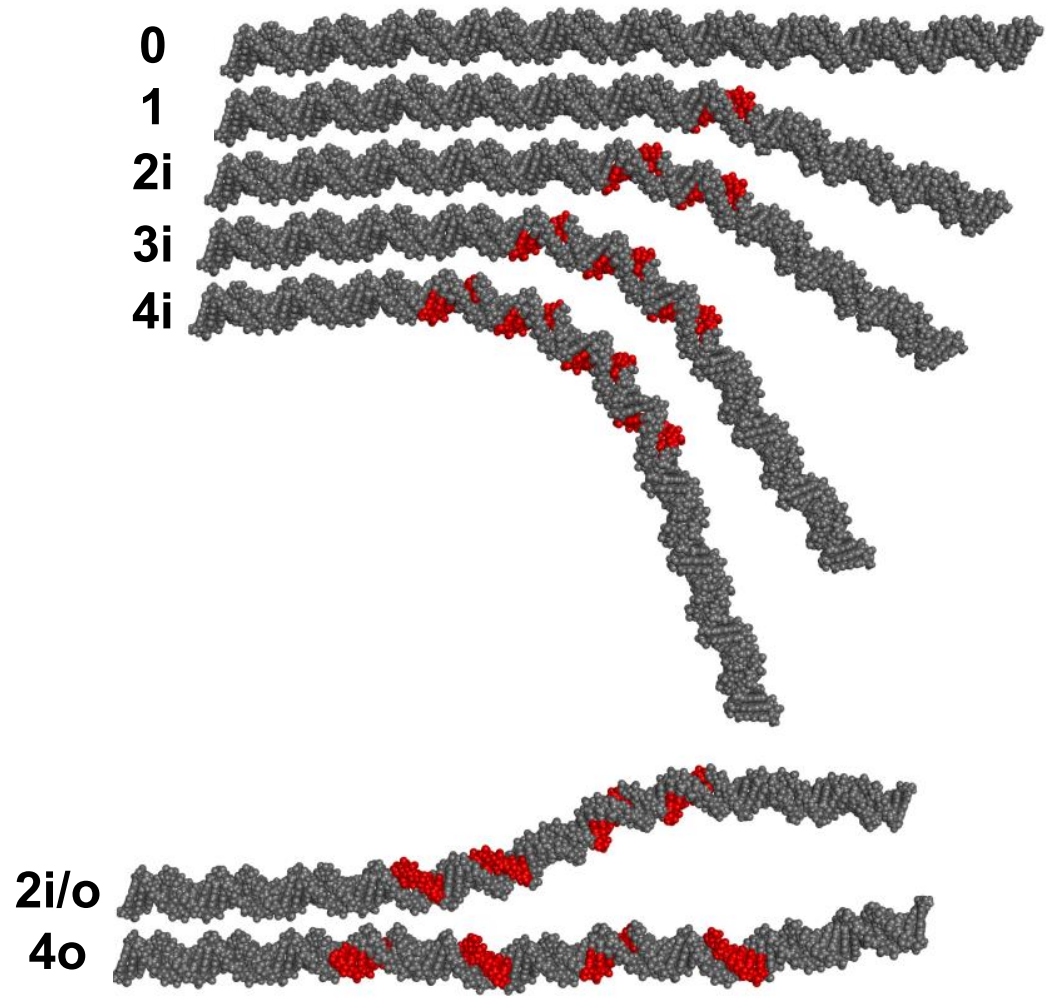

Figure 1. Schematic of 98-bp DNA fragments. (A) Sequences of the DNA constructs studied here with $\mathrm{A}_{6}$-tracts shown in bold red. Possible unpaired $3^{\prime}$ deoxyadenosine residues from non-template-dependent terminal transferase activity of Taq polymerase are not shown. The first four sequence names (samples 0 to 4 i) indicate the number of phased $A_{6}$-tracts in the sample. Sample $2 \mathrm{i}$ /o contains two pairs of in-phase $\mathrm{A}_{6}$-tracts; the two pairs of phased $\mathrm{A}_{6}$-tracts are out-of-phase with each other. Sample 4o has four $\mathrm{A}_{6}$-tracts separated by 16 residues from each other. (B) Depiction of the shapes of the DNA fragments with A-tracts shown in red. Molecular models were rendered with PyMOL. 
Netropsin is a small molecule with antiviral and antibiotic properties that preferentially binds AT-rich DNA sequences, including DNA A-tracts [71]. Figure 2A shows the chemical structure of netropsin dihydrochloride. Figure $2 \mathrm{~B}$ is a visual representation of netropsin (shown in teal spheres) binding the minor groove of an A-tract in a short DNA helix.

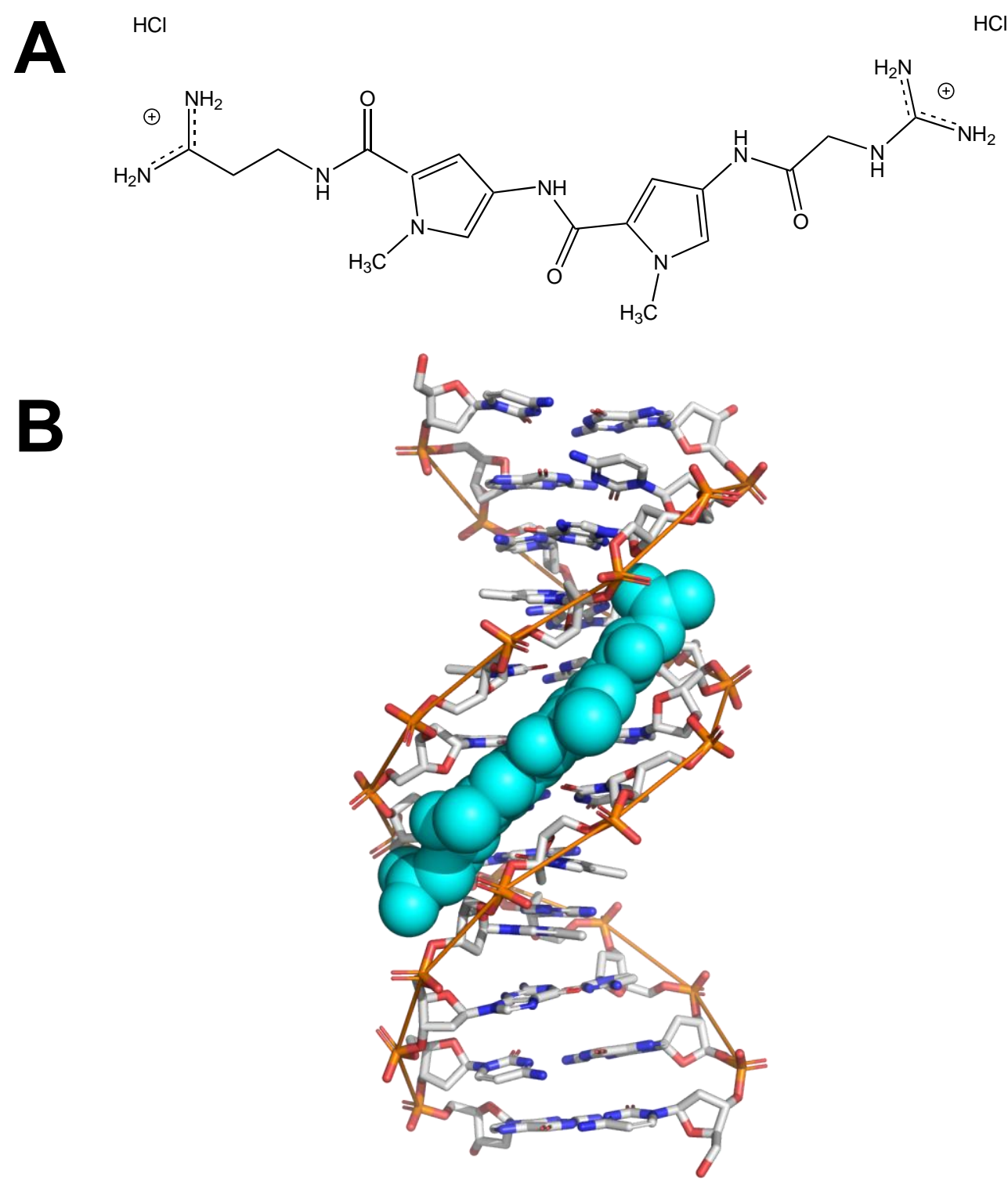

Figure 2. Netropsin. (A) Chemical structure of netropsin dihydrochloride, created using ChemDraw. (B) Image depicting netropsin (teal spheres) binding the minor groove of DNA (PDB file 121D), created using PyMOL. The hypothesis is that netropsin binding eliminates the curvature of A-tracts.

\subsection{Electrophoretic Mobility of DNA in Polyacrylamide Gels}

The electrophoretic mobility of DNA in polyacrylamide gels can be calculated from Equation (1) (see Materials and Methods) by measuring the distance the analyte travels in a set amount of time. A representative image, showing the migration of the A-tract samples in polyacrylamide gels cast and run in 0.5X TBE buffer containing $30 \mathrm{mM}$ Tris $^{+}$ ions, is presented in Figure 3A (left set of bands are without netropsin and right set of bands are pre-mixed with $0.01 \mathrm{mM}$ netropsin). The mobilities of samples $1,2 \mathrm{i}, 3 \mathrm{i}$, and $4 \mathrm{i}$ decrease progressively with an increasing number of phased A-tracts, as expected from previous studies in the literature [20,72]. The mobility of fragment $4 i$, with four in-phase A-tracts, is significantly reduced compared to that of fragment $2 \mathrm{i} / \mathrm{o}$, indicating that mobility 
is determined by the arrangement of the A-tracts in the sample, and not the number of A-tracts. Samples pre-mixed with $0.01 \mathrm{mM}$ netropsin display a marked diminution of the observed mobility decrease with in-phase A-tracts (Figure 3A, right set of bands). The mobilities observed for the various A-tract constructs in polyacrylamide gels are compared by calculating the difference in mobility between fragment 0 , with no A-tracts, and the fragments with one or more A-tracts (Figure 3B). Since the mobilities observed for the in-phase A-tract constructs are smaller than those observed for fragment 0 , the mobility differences $\Delta \mu=\mu$ (A-tract $)-\mu(0)$ are negative in sign. For the interested reader, all of the mobilities determined in this work are presented in Supplementary Material Table S1.
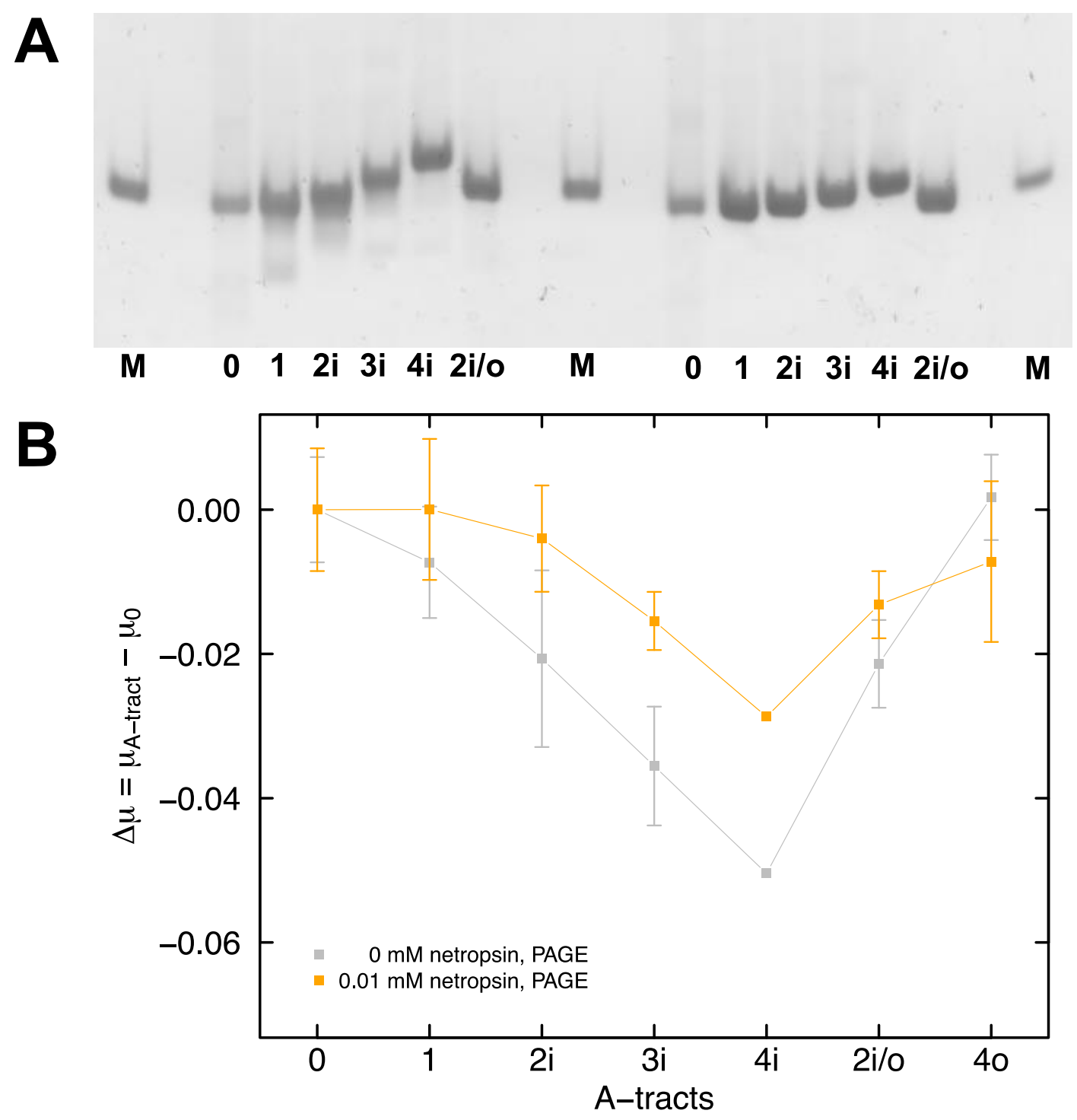

Figure 3. Polyacrylamide gel electrophoresis. (A) Representative image of the A-tract samples run in a polyacrylamide gel containing $30 \mathrm{mM}$ Tris ${ }^{+}$ions without netropsin (left set of bands) or premixed with $0.01 \mathrm{mM}$ netropsin (right set of bands). The various DNA samples are identified at the bottom of each lane. The lanes labeled M correspond to a 100-bp marker. (B) The differences in mobility between sample 0, with no A-tracts, and the A-tract-containing samples are plotted as a function of the number and arrangement of the A-tracts in the absence (gray) or presence (orange) of $0.01 \mathrm{mM}$ netropsin. The lines are drawn to guide the eye. 


\subsection{Electrophoretic Mobility of DNA in Free Solution}

The apparent electrophoretic mobility of DNA in free solution can be calculated from Equation (1) by measuring the migration time for an analyte to travel a set distance (41.5 $\mathrm{cm}$ for the capillaries used in this work). In capillary electrophoresis, the apparent mobility is the sum of the true electrophoretic mobility of the analyte and the mobility due to the electroosmotic flow (EOF) of the solvent. We began with fragments $4 \mathrm{o}$ and $4 \mathrm{i}$. Each of these constructs contains four A-tracts, either in-phase or out-of-phase. Hence, any cation localization around the A-tract minor groove should be the same for both samples, and any mobility difference can be attributed entirely to differences in shape. Replicate runs of individual injections of $4 \mathrm{o}$ (red) and $4 \mathrm{i}$ (blue) are shown in Figure 4A. The DNA concentrations of the injected samples $(53 \mathrm{ng} / \mu \mathrm{L}$ for $4 \mathrm{o}$ and $64 \mathrm{ng} / \mu \mathrm{L}$ for $4 \mathrm{i}$ ) are predicted to result in a peak area ratio of 0.84:1. The area under the curve values found from numerical integration using Simpson's rule for the four injections in Figure 4A yield an average area ratio of $0.76: 1$. This is in reasonable agreement given the approximate nature of the integration method.
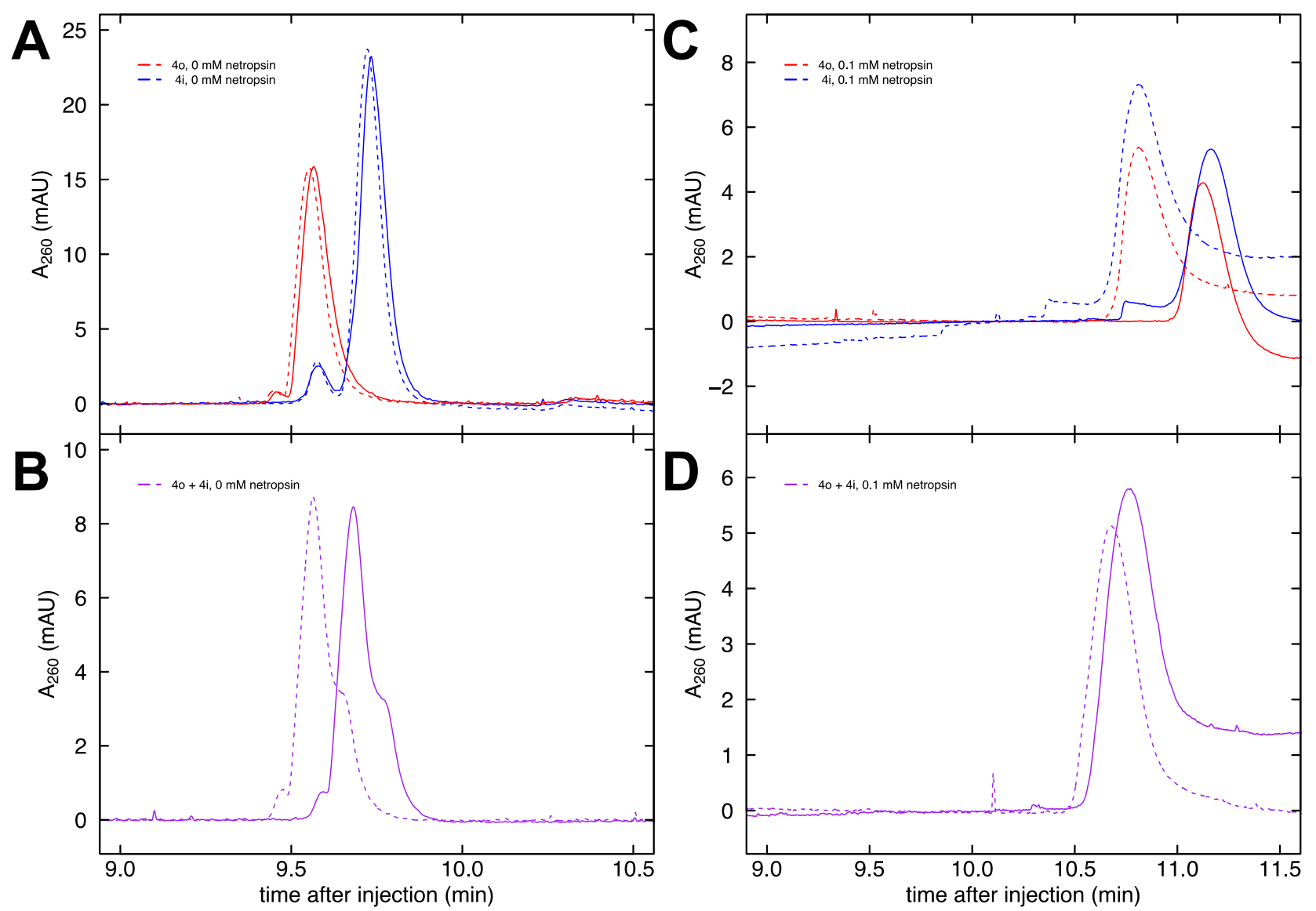

Figure 4. Electropherograms of DNA in free solution. (A) Electropherograms of separate runs of fragments $4 \mathrm{o}$ (red) and $4 \mathrm{i}$ (blue) in buffer containing $33 \mathrm{mM} \mathrm{Na}^{+}$ions in the absence of netropsin. (B) Electropherograms of the co-injection of $4 \mathrm{o}$ and $4 \mathrm{i}$ in buffer containing $33 \mathrm{mM} \mathrm{Na}^{+}$ions in the absence of netropsin. (C) Electropherograms of separate runs of fragments $4 \mathrm{o}$ (red) and $4 \mathrm{i}$ (blue) in buffer containing $33 \mathrm{mM} \mathrm{Na}^{+}$ions and $0.1 \mathrm{mM}$ netropsin. (D) Electropherograms of the co-injection of $4 \mathrm{o}$ and $4 \mathrm{i}$ in buffer containing $33 \mathrm{mM} \mathrm{Na}^{+}$ions and $0.1 \mathrm{mM}$ netropsin.

To reduce the number of runs performed and to largely eliminate the effects of EOF, the method of co-injection is favored. Samples $4 \mathrm{o}$ and $4 \mathrm{i}$ were pre-mixed in a concentration ratio of approximately 5:2 for these co-injections (purple), so the raw data in Figure 4B show a pronounced peak (4o) and a smaller shoulder (4i). Specifically, $48 \mu \mathrm{L}$ of $4 \mathrm{o}$ was mixed with $17 \mu \mathrm{L}$ of $4 \mathrm{i}$, resulting in a concentration ratio of 2.36:1 (with $4 \mathrm{i}$ now the lesser 
component, as intended). The area under the curve values for Figure 4B are calculated from fitted Gaussians (c.f. Figure 5A) and give an average area ratio of 2.43:1, which is in good agreement with the expected ratio based on the concentrations. The difference in retention time from the main peak to the shoulder in Figure 4B is very reproducible since it is largely independent of the effects of EOF. In the absence of netropsin, the mobility difference between the $4 \mathrm{o}$ and $4 \mathrm{i}$ fragments is comparable between the separate injection and co-injection methods.
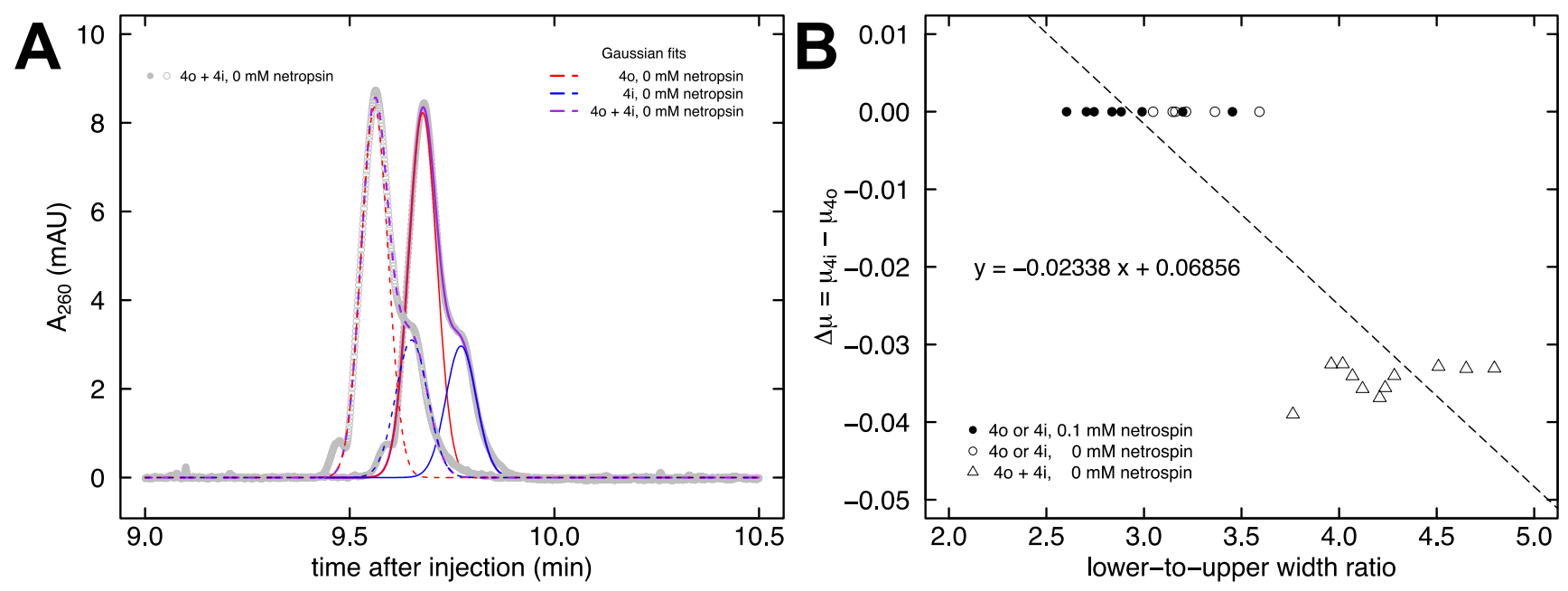

Figure 5. Quantification method. (A) The raw data of a co-injection electropherogram (gray) are fit with two Gaussian functions: $4 \mathrm{o}$ in red and $4 \mathrm{i}$ in blue. The sum of the two Gaussians is in purple. (B) Standard curve for the lower-to-upper width ratio method of analysis. The circles represent single injections of $4 \mathrm{i}$ or $4 \mathrm{o}$, triangles represent co-injection of $4 \mathrm{i}$ with $4 \mathrm{o}$, unfilled symbols represent no netropsin in the buffer, and filled symbols represent $0.1 \mathrm{mM}$ netropsin in the buffer. The equation of the best fit line is given.

Given the variability in EOF between runs, many more replicates are needed to obtain meaningful results from separate injections versus co-injections. Generally, month-tomonth variability is greater than the typical variability observed within a given day. This can be seen from the replicate runs (dashed line data collected in a different month than solid line data) shown in Figure 4C of individual injections of 4o (red) and 4i (blue) with the addition of $0.1 \mathrm{mM}$ netropsin to the buffer. However, it is clear from co-injection of $4 \mathrm{o}$ and $4 \mathrm{i}$ (purple) in the presence of $0.1 \mathrm{mM}$ netropsin that the runs are now characterized by a single peak and that the previously observed mobility difference in the absence of netropsin (Figure 4B) is greatly diminished (Figure 4D). Compared to Figure 4A and 4B, Figure $4 \mathrm{C}$ and $4 \mathrm{D}$ display a shift in retention times with the addition of netropsin to the buffer. Small single-stranded DNA oligomers that do not interact with netropsin also exhibit this behavior (data not shown). We attribute this result to differences in the relative concentrations, equivalent conductivities, cation sizes, and viscosities from the changing composition of the background electrolyte.

The raw data from Figure 4B, which shows a pronounced peak and a smaller shoulder, can be fit with two Gaussian functions [73]. In Figure 5A, each purple line is the sum of the two fit Gaussian curves (4o in red and 4i in blue), which aligns well with the gray symbols representing the raw data. For the runs with $0.1 \mathrm{mM}$ netropsin added to the buffer, the presence of an observable shoulder in the data is lacking (c.f. Figure 4D), which makes it difficult to apply the Gaussian fit method to obtain quantitative information about any remaining mobility differences. Instead, a new method was devised comparing the full width at $17 \%$ and $83 \%$ max peak height in the raw data. For an ideal Gaussian curve, the ratio of these full widths (at 0.175699 max relative to 0.824301 max) equals three. This is what is observed for samples $4 \mathrm{o}$ and $4 \mathrm{i}$ individually in either the presence or absence of netropsin (Figure 5B, circles). As discussed above, the co-injection of both samples together 
in the absence of netropsin produces a larger peak with a smaller shoulder that can be fit with Gaussians (Figure 5A). The presence of a smaller shoulder below the $83 \%$ max height threshold increases the lower-to-upper width ratio to approximately 4.5 , since the upper width remains unchanged (Figure $5 \mathrm{~B}$, triangles). Figure $5 \mathrm{~B}$ shows the standard curve that was constructed from these data to allow for the quantification of the mobility difference from co-injections at arbitrary concentrations of netropsin.

\subsection{Dependence of Free Solution Mobility Difference on Netropsin Concentration}

The dependence of the free solution mobility difference on netropsin concentration was investigated in more detail. Co-injections of fragments 40 and $4 \mathrm{i}$ were performed as the concentration of netropsin in the buffer increased. Figure 6A shows that the distinct feature of a shoulder diminishes with an increasing netropsin concentration. Since the likely cause of the original disparity in mobility between fragments 40 and $4 \mathrm{i}$ is shape, we interpret the reversal of this mobility disparity with increasing netropsin concentration as the two fragments converging on a similar shape. In particular, this finding suggests that netropsin binding results in a straightening of the curved fragment $4 \mathrm{i}$.
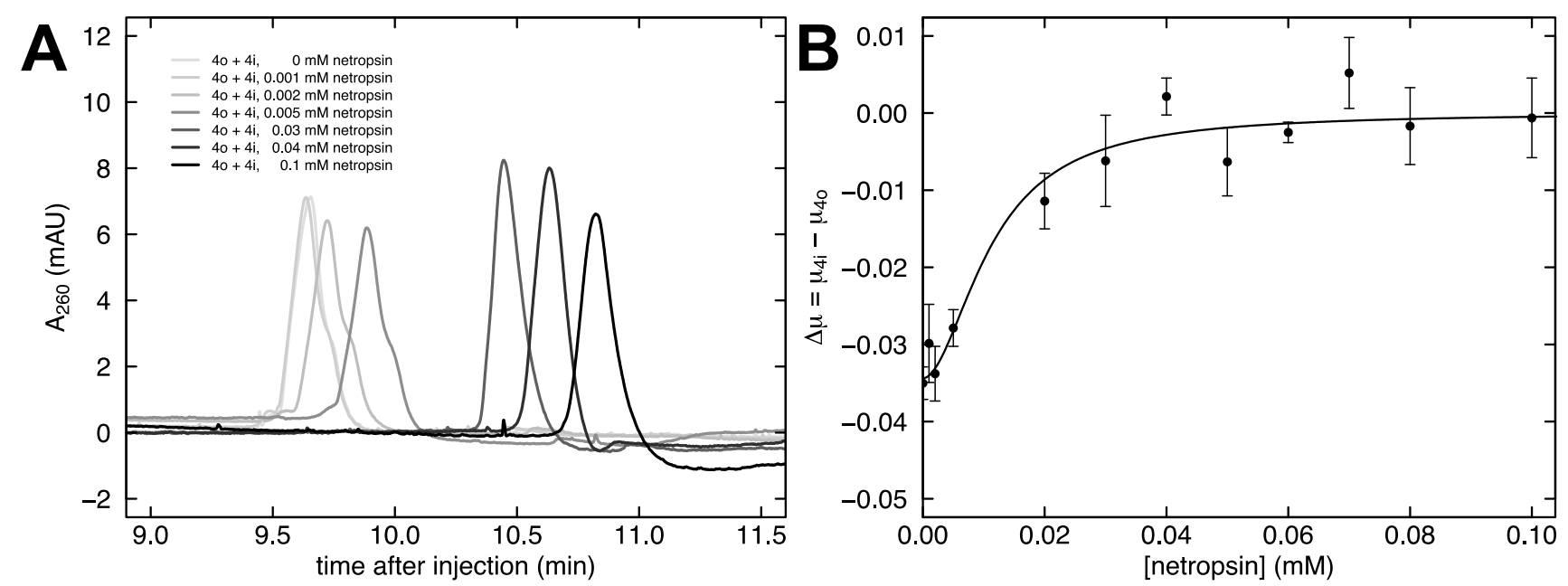

Figure 6. Effect of netropsin concentration. (A) Co-injections of $4 \mathrm{o}$ and $4 \mathrm{i}$ at varying netropsin concentrations from $0 \mathrm{mM}$ netropsin (gray) to $0.1 \mathrm{mM}$ netropsin (black). (B) The mobility difference between $4 \mathrm{o}$ and $4 \mathrm{i}$ at various netropsin concentrations. The curved line corresponds to the fit of a four-parameter sigmoidal function.

The relationship between the mobility difference of 40 and $4 \mathrm{i}$ and the concentration of netropsin added to the buffer is shown in Figure 6B. A four-parameter sigmoidal function was used to fit the data in Figure 6B. Increasing the netropsin concentration brings the mobility difference to a plateau near zero, and the midpoint of the transition occurs at $0.0112 \mathrm{mM}$ netropsin.

\subsection{Electrophoretic Mobility of A-Tract Constructs}

For capillary electrophoresis experiments with the remaining constructs, co-injection of each construct with $4 \mathrm{i}$ at the inlet was followed by negative polarity electrophoresis to mobilize the fragments past the detector. All of the fragments exhibited a difference in free solution mobility relative to $4 \mathrm{i}$ when electrophoresed in sodium phosphate buffer, $\mathrm{pH}$ 7.28 containing $33 \mathrm{mM}$ sodium ions and no netropsin. Figure 7A plots the difference in mobility between each A-tract containing DNA fragment and fragment 0 in the absence of netropsin (black), and the accompanying attenuated mobility difference with addition of $0.05 \mathrm{mM}$ netropsin (green). A similar mobility for all of the DNA fragments in the presence of saturating netropsin, particularly fragments $4 \mathrm{i}, 2 \mathrm{i} / \mathrm{o}$, and 40 , which each contain four A-tracts, implies that they are converging on a similar shape, since shape is the only reasonable explanation for the differences in mobility observed in the absence of 
netropsin. This result in free solution mirrors the result observed during gel electrophoresis (Figure 3B).

The difference in free solution mobility between fragment 0 and the A-tract constructs is almost completely eliminated in the presence of $0.1 \mathrm{mM}$ netropsin (Figure 7B, cyan). We interpret this result as netropsin binding driving all of the DNA fragments into straight conformations. We have previously shown that A-tract curvature is also lost in solutions containing moderate concentrations of hydrophobic cations, possibly because the bulky tetrabutylammonium ions $\left(\mathrm{TBA}^{+}\right)$cannot organize as well around the narrow A-tract minor groove [20]. Since netropsin and $\mathrm{TBA}^{+}$each individually promote a straighter Atract, we sought to investigate the combined effects. We found that, independent of the number of A-tracts and their arrangement in the DNA fragments, the mobility difference observed in polyacrylamide gels run in tetrabutylammonium cacodylate buffer, $\mathrm{pH} 6.6$ (containing $35 \mathrm{mM} \mathrm{TBA}^{+}$ions) is largely absent when $0.01 \mathrm{mM}$ netropsin is added to the buffer (Figure 7B, magenta). Assessed individually, these concentrations are unable to eliminate the A-tract curvature. Therefore, netropsin appears to function synergistically with TBA ions in reducing the A-tract curvature.
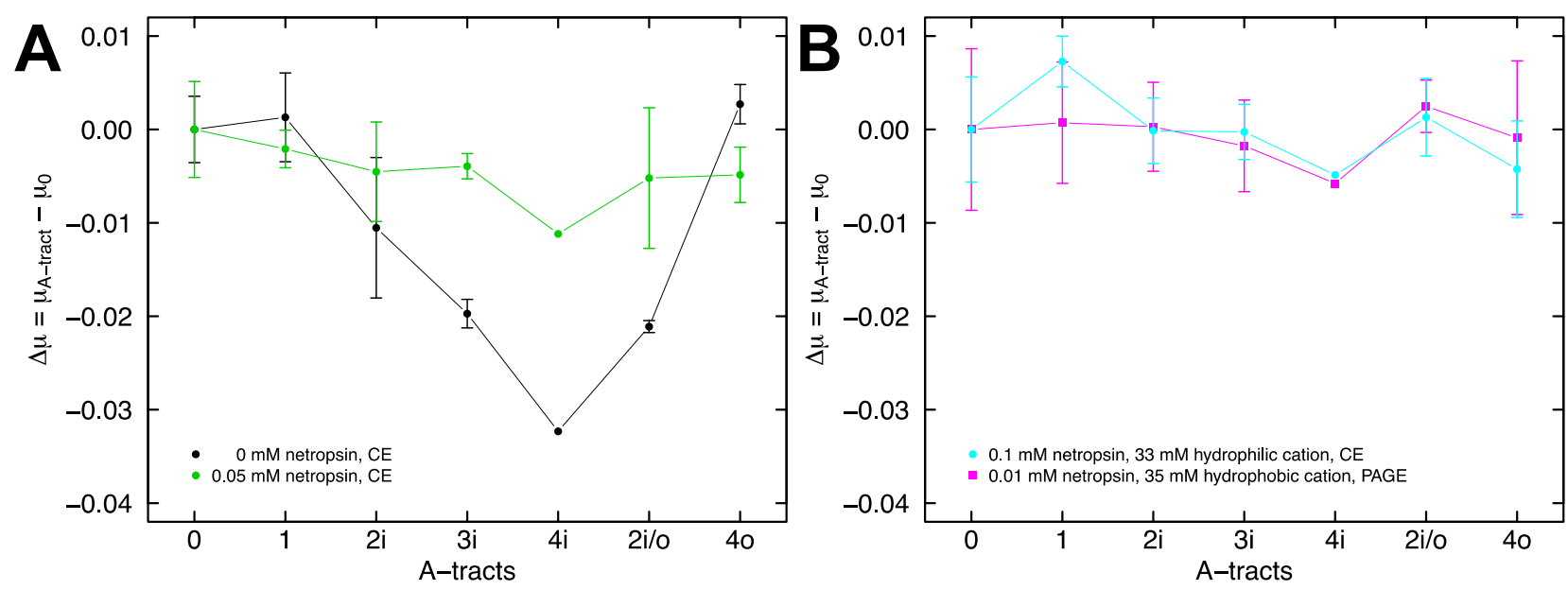

Figure 7. Electrophoresis of A-tract constructs. (A) Sodium phosphate buffer, $\mathrm{pH} 7.28$ containing $33 \mathrm{mM} \mathrm{Na}^{+}$ions, was used for all capillary electrophoresis experiments. Plot of the free solution mobility difference between A-tract containing DNA fragments and fragment 0 in the absence (black) or presence (green) of $0.05 \mathrm{mM}$ netropsin. The lines are drawn to guide the eye. (B) Free solution mobility difference in the presence of $0.1 \mathrm{mM}$ netropsin (cyan) and gel mobility difference for the combination of $35 \mathrm{mM} \mathrm{TBA}^{+}$ions and $0.01 \mathrm{mM}$ netropsin (magenta). The lines are drawn to guide the eye.

\section{Materials and Methods}

\subsection{DNA Fragments}

The DNA fragments in this work were synthesized by polymerase chain reaction (PCR) from plasmids previously described [20]. Briefly, PCR reactions $(100 \mu \mathrm{L})$ included $20 \mathrm{ng}$ plasmid template, $0.4 \mu \mathrm{M}$ UNI1 (5'-AGCCTAGCCTATGACATGAC) and $0.4 \mu \mathrm{M}$ UNI2 (5'-GAGGTGAGGTTGCATTGCAT) (Integrated DNA Technologies, Coralville, IA, USA), $100 \mu \mathrm{g} / \mathrm{mL}$ BSA, Taq DNA polymerase buffer (Invitrogen, Waltham, MA, USA), $2 \mathrm{mM}$ $\mathrm{MgCl}_{2}, 0.2 \mathrm{mM}$ each dNTP, and $5 \mathrm{U}$ Taq DNA polymerase (Invitrogen). Cycle conditions were $94{ }^{\circ} \mathrm{C}(3 \mathrm{~min}), 30 \mathrm{cycles}$ of $\left[94{ }^{\circ} \mathrm{C}(5 \mathrm{~s}), 55^{\circ} \mathrm{C}(15 \mathrm{~s})\right.$, and $\left.72{ }^{\circ} \mathrm{C}(30 \mathrm{~s})\right], 72{ }^{\circ} \mathrm{C}(5 \mathrm{~min})$, followed by $4{ }^{\circ} \mathrm{C}$. Following PCR, the DNA samples were purified using a GeneJET PCR Purification Kit (Thermo, Waltham, MA, USA).

\subsection{Buffers}

A $20 \mathrm{mM}$ sodium phosphate buffer, $\mathrm{pH} 7.28$ containing $33 \mathrm{mM}$ sodium ions, was prepared by mixing $13.5 \mathrm{~mL}$ of $1 \mathrm{M} \mathrm{Na}_{2} \mathrm{HPO}_{4}$ with $6.5 \mathrm{~mL}$ of $1 \mathrm{M} \mathrm{NaH}_{2} \mathrm{PO}_{4}$ and $980 \mathrm{~mL}$ of water. Stock buffers of 25X TBE (2.5 M Tris base, $2.75 \mathrm{M}$ boric acid, $0.05 \mathrm{M}$ EDTA, 
$\mathrm{pH} 8.3$ ) and $50 \mathrm{mM}$ TBA-cacodylate (50 mM tetrabutylammonium hydroxide and $50 \mathrm{mM}$ cacodylic acid, $\mathrm{pH}$ 6.6) were also prepared. Since the Tris base is half ionized at its $\mathrm{pKa}$ of $8.07\left(25^{\circ} \mathrm{C}\right)$, the concentration of Tris ${ }^{+}$ions in $0.5 \mathrm{X}$ TBE buffer is $\sim 30 \mathrm{mM}$ according to the Henderson-Hasselbalch equation. Similarly, the $\mathrm{TBA}^{+}$concentration in the $50 \mathrm{mM}$ TBA-cacodylate buffer is $\sim 35 \mathrm{mM}$, since cacodylic acid is half ionized at its $\mathrm{pKa}$ of 6.27 $\left(25^{\circ} \mathrm{C}\right)$. To avoid confusion, buffers are described by the concentration of the cation, and not the ionic strength of the solution nor the anion concentration. We previously showed that A-tract curvature is lost with increasing concentration of monovalent cations in the buffer [20]. Since cation concentration impacts the magnitude of the observed A-tract curvature, we used a consistent cation concentration (30-35 mM) in this work to avoid confounding effects from cation concentration.

For capillary electrophoresis, a $1 \mathrm{mM}$ stock of netropsin dihydrochloride (Enzo Life Sciences, Farmingdale, NY, USA) was prepared in buffer and diluted to the indicated final concentration, ranging from $0.0005 \mathrm{mM}$ to $0.1 \mathrm{mM}$. For gel electrophoresis, the netropsin was added to the DNA sample but not included in the running buffer to conserve resources.

\subsection{Polyacrylamide Gel Electrophoresis (PAGE)}

Polyacrylamide gels containing 5\% total acrylamide and 5\% bisacrylamide crosslinker were cast in running buffer at room temperature. A mixture of $40 \%$ acrylamide and bisacrylamide solution, 19:1 (BioRad, Hercules, CA, USA) diluted in running buffer with $0.1 \%$ $(v / v) N, N, N^{\prime}, N^{\prime}$-tetramethylethylenediamine (TEMED, Sigma, St. Louis, MO, USA) and $0.1 \%(w / v)$ freshly dissolved ammonium persulfate (Sigma), was slowly poured between glass plates $(14.5 \times 22.5 \mathrm{~cm})$ assembled with 1.5 -mm spacers. Gels were pre-electrophoresed for $20 \mathrm{~min}$, then DNA samples and 100-bp ladder (Invitrogen) were loaded. Using an electric field strength of 8-12 V/cm, the gels were run until markers had migrated $50-90 \%$ the length of the gel. Following electrophoresis, gels were stained with 1X Sybr Green I (Invitrogen) in running buffer for $20 \mathrm{~min}$. Images were then obtained using a Typhoon FLA 7000 (GE Healthcare, Chicago, IL, USA), and migration distances (50 micron/pixel) were measured from these digital images.

\subsection{Capillary Electrophoresis (CE)}

The free solution mobilities of the DNA samples were measured with an Agilent 7100 Capillary Electrophoresis System (Agilent, Santa Clara, CA, USA). All measurements were made in the reverse polarity mode with UV detection at $260 \mathrm{~nm}$ using a green interface from Agilent. The capillaries were coated internally with linear polyacrylamide (Polymicro Technologies, Phoenix, AZ, USA) to minimize the electroosmotic flow of the solvent. The capillaries were $50.0 \pm 0.2 \mathrm{~cm}$ in length $(41.5 \pm 0.1 \mathrm{~cm}$ to the detector), had a $75 \pm 3 \mu \mathrm{m}$ internal diameter, and were mounted in a $20.0 \pm 0.1^{\circ} \mathrm{C}$ temperaturecontrolled cassette. Following preconditioning of the capillary with a hydrodynamic flush (at $1379 \mathrm{mbar}$ for $240 \mathrm{~s}$ ) and applied voltage ( $-10.1 \mathrm{kV}$ for $60 \mathrm{~s}$ ), the DNA samples were injected hydrodynamically at 34 mbar $(0.5 \mathrm{psi})$ for $3 \mathrm{~s}$; the sample plug occupied $\sim 0.72 \%$ of the capillary length. A voltage of $-10.1 \mathrm{kV}$ applied over the $50 \mathrm{~cm}$ total length of the capillary produced a field strength of $202 \mathrm{~V} / \mathrm{cm}$; the current was always $125 \mu \mathrm{A}$ or less.

\subsection{Calculation of Mobility}

Gel electrophoresis allows for charged particles to separate based on their charge density, size, and shape as they are driven by an electric field. The pores of a slab gel cause steric hinderance to allow size separation during gel electrophoresis, and multiple samples can be processed in parallel within the same gel. Capillary electrophoresis can be used to measure the free solution mobility of the DNA fragments without some of the physical hindrance found in gel electrophoresis. CE also allows for faster run times and less waste 
when compared to gel electrophoresis [74]. The apparent mobility $\left(\mu_{\mathrm{a}}, \mathrm{cm}^{2} \mathrm{~V}^{-1} \mathrm{~s}^{-1}\right)$ of an analyte, such as a DNA sample, is calculated using Equation (1):

$$
\mu_{\mathrm{a}}=\frac{L}{E \cdot t}
$$

based on the length $(L, \mathrm{~cm})$ of the capillary from the injection site to the detector or the distance migrated in a gel, the applied electric field strength $(E, \mathrm{~V} / \mathrm{cm})$, and the migration time $(t, \mathrm{~s})$. All mobilities are presented in mobility units (m.u.), where $1 \mathrm{~m} . \mathrm{u} .=1 \times 10^{-4} \mathrm{~cm}^{2} \mathrm{~V}^{-1} \mathrm{~s}^{-1}$.

Electroosmotic flow (EOF) creates a solvent front caused by electrostatic wall-solvent interactions and varies between runs. For DNA samples, the CE instrument is run in negative polarity mode (negative electrode at the inlet) and EOF is an opposing force to DNA migration. Knowing the magnitude of mobility due to EOF within a capillary allows for both finding the absolute electrophoretic mobility of the DNA sample and confirming the direction the DNA sample will migrate during electrophoresis. Minimizing the mobility due to EOF allows for faster run times and increased reproducibility between runs [74]. For this experimental work, the mobility due to EOF was kept very low with linear polyacrylamide-coated capillaries [75], but did vary slightly from run to run because of transient changes in capillary coating. The mobility due to EOF was measured in every new capillary and new background electrolyte [76]. Unless otherwise stated, co-injections were used to determine a relative mobility between samples, circumventing the variability of mobility due to EOF between runs. The co-injections contained DNA fragment $4 \mathrm{i}$ with each of the other fragments of interest, with $4 \mathrm{i}$ intentionally having a lower concentration than the second fragment. The difference in concentration allowed for the identification of the fragments because the magnitude of the UV absorbance signal directly reflects the amount of sample being detected. Fragment $4 i$ was chosen for co-injection since it has the slowest migration time of all of the fragments. Thus, $4 \mathrm{i}$ has the largest difference in mobility with the other fragments and allows for the best resolution of differences from the co-injections.

The free solution and gel mobilities of the various DNA samples are reported as differences in mobility $(\Delta \mu)$ between sample 0 , with no A-tracts, and the mobility of an A-tract-containing sample, such as sample 3i: $\Delta \mu=\mu \mathrm{a}(3 \mathrm{i})-\mu \mathrm{a}(0)$.

\section{Conclusions}

The biological function of A-tracts is not fully understood. The mobility difference between DNA fragments with the same number of A-tracts but with different orientations was systematically examined in order to study DNA shape. This research has shown that the mobility decrement caused by A-tracts in both gels and free solution is reversed by saturating amounts of the small molecule netropsin. For capillary electrophoresis, the method of co-injection is a useful way to compare the mobilities of DNA fragments, since it accounts for EOF variation between runs. Using co-injections of the A-tract constructs, all fragments had a mobility difference from $4 \mathrm{i}$ when netropsin was withheld from the buffer. The addition of netropsin decreased the mobility differences between the fragments. At saturating netropsin concentrations there was essentially no mobility difference between any co-injection. Netropsin reverses the mobility decrement caused by differences in shape through a straightening of DNA A-tracts and functions synergistically with bulky hydrophobic cations. This further expands the potential usefulness of netropsin in therapeutics.

Supplementary Materials: The following are available online: Table S1, table of electrophoretic mobilities observed for the A-tract constructs.

Author Contributions: Conceptualization, J.M. and J.P.P.; methodology, J.M. and J.P.P.; validation, J.M. and J.P.P.; formal analysis, J.M. and J.P.P.; writing —original draft preparation, J.M. and J.P.P.; writing - review and editing, J.P.P.; visualization, J.M. and J.P.P.; project administration, J.P.P. All authors have read and agreed to the published version of the manuscript. 
Funding: This research received no external funding.

Institutional Review Board Statement: Not applicable.

Informed Consent Statement: Not applicable.

Data Availability Statement: Not applicable.

Acknowledgments: The authors would like to thank Kelli Gaffney for technical assistance and guidance. This work was supported by the University of Northern Iowa's College of Humanities, Arts, and Sciences.

Conflicts of Interest: The authors declare no conflict of interest.

Sample Availability: Samples of the DNA constructs are available from the authors.

\section{References}

1. Marini, J.C.; Levene, S.D.; Crothers, D.M.; Englund, P.T. Bent Helical Structure in Kinetoplast DNA. Proc. Natl. Acad. Sci. USA 1982, 79, 7664-7668. [CrossRef]

2. $\mathrm{Wu}, \mathrm{H} .-\mathrm{M} . ;$ Crothers, D.M. The Locus of Sequence-Directed and Protein-Induced DNA Bending. Nature 1984, $308,509-513$. [CrossRef]

3. Levene, S.D.; Wu, H.M.; Crothers, D.M. Bending and Flexibility of Kinetoplast DNA. Biochemistry 1986, 25, 3988-3995. [CrossRef]

4. Beutel, B.A.; Gold, L. In Vitro Evolution of Intrinsically Bent DNA. J. Mol. Biol. 1992, 228, 803-812. [CrossRef]

5. Stellwagen, N.C. Curved DNA Molecules Migrate Anomalously Slowly in Polyacrylamide Gels Even at Zero Gel Concentration. Electrophoresis 2006, 27, 1163-1168. [CrossRef]

6. Stellwagen, N.C.; Gelfi, C.; Righetti, P.G. The Free Solution Mobility of DNA. Biopolym. Orig. Res. Biomol. 1997, 42, 687-703. [CrossRef]

7. Stellwagen, E. Curved DNA Molecules Migrate Anomalously Slowly in Free Solution. Nucleic Acids Res. 2005, 33, 4425-4432. [CrossRef] [PubMed]

8. Koo, H.-S.; Wu, H.-M.; Crothers, D.M. DNA Bending at Adenine- Thymine Tracts. Nature 1986, 320, 501-506. [CrossRef] [PubMed]

9. Koo, H.S.; Drak, J.; Rice, J.A.; Crothers, D.M. Determination of the Extent of DNA Bending by an Adenine-Thymine Tract. Biochemistry 1990, 29, 4227-4234. [CrossRef] [PubMed]

10. DiGabriele, A.D.; Sanderson, M.R.; Steitz, T.A. Crystal Lattice Packing Is Important in Determining the Bend of a DNA Dodecamer Containing an Adenine Tract. Proc. Natl. Acad. Sci. USA 1989, 86, 1816-1820. [CrossRef]

11. Dickerson, R.E.; Goodsell, D.; Kopka, M.L. MPD and DNA Bending in Crystals and in Solution. J. Mol. Biol. 1996, 256, 108-125. [CrossRef] [PubMed]

12. Strahs, D.; Schlick, T. A-Tract Bending: Insights into Experimental Structures by Computational Models. J. Mol. Biol. 2000, 301, 643-663. [CrossRef] [PubMed]

13. McConnell, K.J.; Beveridge, D.L. Molecular Dynamics Simulations of B'-DNA: Sequence Effects on A-Tract-Induced Bending and Flexibility. J. Mol. Biol. 2001, 314, 23-40. [CrossRef] [PubMed]

14. Balasubramanian, C.; Ojha, R.P.; Maiti, S. Hydration Pattern of A4T4 and T4A4 DNA: A Molecular Dynamics Study. Biochem. Biophys. Res. Commun. 2007, 355, 1081-1086. [CrossRef]

15. MacDonald, D.; Herbert, K.; Zhang, X.; Polgruto, T.; Lu, P. Solution Structure of an A-Tract DNA Bend. J. Mol. Biol. 2001, 306, 1081-1098. [CrossRef]

16. Barbič, A.; Zimmer, D.P.; Crothers, D.M. Structural Origins of Adenine-Tract Bending. Proc. Natl. Acad. Sci. USA 2003, 100, 2369-2373. [CrossRef]

17. Stellwagen, N.C. Anomalous Electrophoresis of Deoxyribonucleic Acid Restriction Fragments on Polyacrylamide Gels. Biochemistry 1983, 22, 6186-6193. [CrossRef]

18. Diekmann, S. Temperature and Salt Dependence of the Gel Migration Anomaly of Curved DNA Fragments. Nucleic Acids Res. 1987, 15, 247-265. [CrossRef]

19. Augustyn, K.E.; Wojtuszewski, K.; Hawkins, M.E.; Knutson, J.R.; Mukerji, I. Examination of the Premelting Transition of DNA A-Tracts Using a Fluorescent Adenosine Analogue. Biochemistry 2006, 45, 5039-5047. [CrossRef]

20. Stellwagen, E.; Peters, J.P.; Maher, L.J.; Stellwagen, N.C. DNA A-Tracts Are Not Curved in Solutions Containing High Concentrations of Monovalent Cations. Biochemistry 2013, 52, 4138-4148. [CrossRef]

21. Stefl, R.; Wu, H.; Ravindranathan, S.; Sklenář, V.; Feigon, J. DNA A-Tract Bending in Three Dimensions: Solving the dA4T4 vs. dT4A4 Conundrum. Proc. Natl. Acad. Sci. USA 2004, 101, 1177-1182. [CrossRef]

22. Snoussi, K.; Leroy, J.-L. Alteration of A $\bullet$ T Base-Pair Opening Kinetics by the Ammonium Cation in DNA A-Tracts. Biochemistry 2002, 41, 12467-12474. [CrossRef]

23. Diekmann, S. DNA Methylation Can Enhance or Induce DNA Curvature. EMBO J. 1987, 6, 4213-4217. [CrossRef]

24. Hagerman, P.J. Pyrimidine 5-Methyl Groups Influence the Magnitude of DNA Curvature. Biochemistry 1990, $29,1980-1983$. [CrossRef] 
25. Zhurkin, V.B.; Ulyanov, N.B.; Gorin, A.A.; Jernigan, R.L. Static and Statistical Bending of DNA Evaluated by Monte Carlo Simulations. Proc. Natl. Acad. Sci. USA 1991, 88, 7046-7050. [CrossRef]

26. Hagerman, P.J.; Ramadevi, V. Application of the Method of Phage T4 DNA Ligase-Catalyzed Ring-Closure to the Study of DNA Structure: I. Computational Analysis. J. Mol. Biol. 1990, 212, 351-362. [CrossRef]

27. Lankaš, F.; Cheatham, T.E.; Hobza, P.; Langowski, J.; Šponer, J. Others Critical Effect of the N2 Amino Group on Structure, Dynamics, and Elasticity of DNA Polypurine Tracts. Biophys. J. 2002, 82, 2592-2609. [CrossRef]

28. Tereshko, V.; Minasov, G.; Egli, M. A “Hydrat-Ion” Spine in a B-DNA Minor Groove. J. Am. Chem. Soc. 1999, 121, $3590-3595$. [CrossRef]

29. Hamelberg, D. Effect of a Neutralized Phosphate Backbone on the Minor Groove of B-DNA: Molecular Dynamics Simulation Studies. Nucleic Acids Res. 2002, 30, 3615-3623. [CrossRef] [PubMed]

30. Madhumalar, A.; Bansal, M. Structural Insights into the Effect of Hydration and Ions on A-Tract DNA: A Molecular Dynamics Study. Biophys. J. 2003, 85, 1805-1816. [CrossRef]

31. Subirana, J.A.; Soler-López, M. Cations as Hydrogen Bond Donors: A View of Electrostatic Interactions in DNA. Annu. Rev. Biophys. Biomol. Struct. 2003, 32, 27-45. [CrossRef]

32. Yonetani, Y.; Kono, H. Sequence Dependencies of DNA Deformability and Hydration in the Minor Groove. Biophys. J. 2009, 97, 1138-1147. [CrossRef] [PubMed]

33. Zhu, X.; Schatz, G.C. Molecular Dynamics Study of the Role of the Spine of Hydration in DNA A-Tracts in Determining Nucleosome Occupancy. J. Phys. Chem. B 2012, 116, 13672-13681. [CrossRef] [PubMed]

34. Woods, K.K. The Role of Minor Groove Functional Groups in DNA Hydration. Nucleic Acids Res. 2003, 31, 1536-1540. [CrossRef] [PubMed]

35. Harvey, S.C.; Dlakic, M.; Griffith, J.; Harrington, R.; Park, K.; Sprous, D.; Zacharias, W. What Is the Basis of Sequence-Directed Curvature in DNAs Containing A Tracts? J. Biomol. Struct. Dyn. 1995, 13, 301-307. [CrossRef]

36. Sprous, D.; Zacharias, W.; Wood, Z.A.; Harvey, S.C. Dehydrating Agents Sharply Reduce Curvature in DNAs Containing A Tracts. Nucleic Acids Res. 1995, 23, 1816-1821. [CrossRef] [PubMed]

37. Dlakic, M.; Park, K.; Griffith, J.D.; Harvey, S.C.; Harrington, R.E. The Organic Crystallizing Agent 2-Methyl-2, 4-Pentanediol Reduces DNA Curvature by Means of Structural Changes in A-Tracts. J. Biol. Chem. 1996, 271, 17911-17919. [CrossRef]

38. Lu, Y.; Stellwagen, E.; Stellwagen, N.C. Effect of Organic Cosolvents on the Free Solution Mobility of Curved and Normal DNA Molecules. Electrophoresis 2006, 27, 1462-1470. [CrossRef]

39. Haran, T.E.; Cohen, I.; Spasic, A.; Yang, K.; Mohanty, U. Dynamics of Curved DNA Molecules: Prediction and Experiment. J. Am. Chem. Soc. 2003, 125, 11160-11161. [CrossRef]

40. Haran, T.E.; Cohen, I.; Spasic, A.; Yang, K.; Mohanty, U. Characteristics of Migration Patterns of DNA Oligomers in Gels and the Relationship to the Question of Intrinsic DNA Bending. J. Am. Chem. Soc. 2004, 126, 2372-2377. [CrossRef] [PubMed]

41. Crothers, D.M.; Haran, T.E.; Nadeau, J.G. Intrinsically Bent DNA. J. Biol. Chem. 1990, 265, 7093-7096. [CrossRef]

42. McCarthy, J.G.; Frederick, C.A.; Nicolas, A. A Structural Analysis of the Bent Kinetoplast DNA from Crithidia Fasciculata by High Resolution Chemical Probing. Nucleic Acids Res. 1993, 21, 3309-3317. [CrossRef] [PubMed]

43. Goodsell, D.S.; Dickerson, R.E. Bending and Curvature Calculations in B-DNA. Nucleic Acids Res. 1994, 22, 5497. [CrossRef] [PubMed]

44. Dršata, T.; Špačková, N.; Jurečka, P.; Zgarbová, M.; Šponer, J.; Lankaš, F. Mechanical Properties of Symmetric and Asymmetric DNA A-Tracts: Implications for Looping and Nucleosome Positioning. Nucleic Acids Res. 2014, 42, 7383-7394. [CrossRef]

45. Mack, D.R.; Chiu, T.K.; Dickerson, R.E. Intrinsic Bending and Deformability at the T-A Step of CCTTTAAAGG: A Comparative Analysis of T-A and A-T Steps within A-Tracts. J. Mol. Biol. 2001, 312, 1037-1049. [CrossRef]

46. Lankas, F.; Spackova, N.; Moakher, M.; Enkhbayar, P.; Sponer, J. A Measure of Bending in Nucleic Acids Structures Applied to A-Tract DNA. Nucleic Acids Res. 2010, 38, 3414-3422. [CrossRef] [PubMed]

47. Møllegaard, N.E.; Lindemose, S.; Nielsen, P.E. Uranyl Photoprobing of Nonbent A/T-and Bent A-Tracts. A Difference of Flexibility? Biochemistry 2005, 44, 7855-7863. [CrossRef]

48. Woods, K.K.; McFail-Isom, L.; Sines, C.C.; Howerton, S.B.; Stephens, R.K.; Williams, L.D. Monovalent Cations Sequester within the A-Tract Minor Groove of [d(CGCGAATTCGCG)]2. J. Am. Chem. Soc. 2000, 122, 1546-1547. [CrossRef]

49. Lindemose, S.; Nielsen, P.E.; Møllegaard, N.E. Polyamines Preferentially Interact with Bent Adenine Tracts in Double-Stranded DNA. Nucleic Acids Res. 2005, 33, 1790-1803. [CrossRef]

50. Hud, N.V.; Polak, M. DNA-Cation Interactions: The Major and Minor Grooves Are Flexible Ionophores. Curr. Opin. Struct. Biol. 2001, 11, 293-301. [CrossRef]

51. Egli, M. DNA-Cation Interactions: Quo Vadis? Chem. Biol. 2002, 9, 277-286. [CrossRef]

52. Tereshko, V.; Minasov, G.; Egli, M. The Dickerson-Drew B-DNA Dodecamer Revisited at Atomic Resolution. J. Am. Chem. Soc. 1999, 121, 470-471. [CrossRef]

53. Ballin, J.D.; Wilson, G.M. Role and Applications of Electrostatic Effects on Nucleic Acid Conformational Transitions and Binding Processes. Appl. Thermodyn. Biol. Mater. Sci. 2011, 129-174.

54. Brukner, I.; Dlakic, M.; Savic, A.; Susic, S.; Pongor, S.; Suck, D. Evidence for Opposite Groove-Directed Curvature of GGGCCC and AAAAA Sequence Elements. Nucleic Acids Res. 1993, 21, 1025-1029. [CrossRef] 
55. Hud, N.V.; Plavec, J. A Unified Model for the Origin of DNA Sequence-Directed Curvature. Biopolymers 2003, 69, 144-158. [CrossRef]

56. Lu, Y.; Stellwagen, N.C. Monovalent Cation Binding by Curved DNA Molecules Containing Variable Numbers of A-Tracts. Biophys. J. 2008, 94, 1719-1725. [CrossRef]

57. Dong, Q.; Stellwagen, E.; Stellwagen, N.C. Monovalent Cation Binding in the Minor Groove of DNA A-Tracts. Biochemistry 2009, 48, 1047-1055. [CrossRef] [PubMed]

58. Watkins, D.; Mohan, S.; Koudelka, G.B.; Williams, L.D. Sequence Recognition of DNA by Protein-Induced Conformational Transitions. J. Mol. Biol. 2010, 396, 1145-1164. [CrossRef] [PubMed]

59. Watkins, D.; Harris, L.-A.; Koudelka, G.B.; Williams, L.D. Protein: Feeling the Groove of DNA. In Frontiers in Nucleic Acids; Sheardy, R.D., Winkle, S.A., Eds.; American Chemical Society: Washington, DC, USA, 2011; Volume 1082, pp. 133-145; ISBN 978-0-8412-2623-4.

60. Poot, M.; Kausch, K.; Köhler, J.; Haaf, T.; Hoehn, H. The Minor-Groove Binding DNA-Ligands Netropsin, Distamycin A and Berenil Cause Polyploidisation via Impairment of the G2 Phase of the Cell Cycle. Cell Struct. Funct. 1990, 15, 151-157. [CrossRef]

61. Jeon, H.; Nam, H.; Lee, J.B. Sustained Release of Minor-Groove-Binding Antibiotic Netropsin from Calcium-Coated Groove-Rich DNA Particles. Pharmaceutics 2019, 11, 387. [CrossRef]

62. Tabernero, L.; Verdaguer, N.; Coll, M.; Fita, I.; Van Der Marel, G.A.; Van Boom, J.H.; Rich, A.; Aymami, J. Molecular Structure of the A-Tract DNA Dodecamer d(CGCAAATTTGCG) Complexed with the Minor Groove Binding Drug Netropsin. Biochemistry 1993, 32, 8403-8410. [CrossRef]

63. Goodsell, D.S.; Kopka, M.L.; Dickerson, R.E. Refinement of Netropsin Bound to DNA: Bias and Feedback in Electron Density Map Interpretation. Biochemistry 1995, 34, 4983-4993. [CrossRef]

64. Nunn, C.M.; Garman, E.; Neidle, S. Crystal Structure of the DNA Decamer d(CGCAATTGCG) Complexed with the Minor Groove Binding Drug Netropsin. Biochemistry 1997, 36, 4792-4799. [CrossRef] [PubMed]

65. Barcelo, F.; Muzard, G.; Mendoza, R.; Revet, B.; Roques, B.P.; Le Pecq, J.B. Removal of DNA Curving by DNA Ligands: Gel Electrophoresis Study. Biochemistry 1991, 30, 4863-4873. [CrossRef] [PubMed]

66. Freyer, M.W.; Buscaglia, R.; Nguyen, B.; Wilson, W.D.; Lewis, E.A. Binding of Netropsin and 4, 6-Diamidino-2-Phenylindole to an A2T2 DNA Hairpin: A Comparison of Biophysical Techniques. Anal. Biochem. 2006, 355, 259-266. [CrossRef]

67. Lewis, E.A.; Munde, M.; Wang, S.; Rettig, M.; Le, V.; Machha, V.; Wilson, W.D. Complexity in the Binding of Minor Groove Agents: Netropsin Has Two Thermodynamically Different DNA Binding Modes at a Single Site. Nucleic Acids Res. 2011, 39, 9649-9658. [CrossRef] [PubMed]

68. Herrera, J.E.; Chaires, J.B. A Premelting Conformational Transition in Poly (DA)-Poly (DT) Coupled to Daunomycin Binding. Biochemistry 1989, 28, 1993-2000. [CrossRef]

69. Alniss, H.Y. Thermodynamics of DNA Minor Groove Binders: Perspective. J. Med. Chem. 2019, 62, 385-402. [CrossRef]

70. Degtyareva, N.N.; Fresia, M.J.; Petty, J.T. DNA Conformational Effects on the Interaction of Netropsin with A-Tract Sequences. Biochemistry 2007, 46, 15136-15143. [CrossRef]

71. Bailly, C.; Chaires, J.B. Sequence-Specific DNA Minor Groove Binders. Design and Synthesis of Netropsin and Distamycin Analogues. Bioconjugate Chem. 1998, 9, 513-538. [CrossRef]

72. Koo, H.-S.; Crothers, D.M. Calibration of DNA Curvature and a Unified Description of Sequence-Directed Bending. Proc. Natl. Acad. Sci. USA 1988, 85, 1763-1767. [CrossRef]

73. Hu, Y.; Liu, J.; Li, W. Resolution of Overlapping Spectra by Curve-Fitting. Anal. Chim. Acta 2005, 538, 383-389. [CrossRef]

74. Durney, B.C.; Crihfield, C.L.; Holland, L.A. Capillary Electrophoresis Applied to DNA: Determining and Harnessing Sequence and Structure to Advance Bioanalyses (2009-2014). Anal. Bioanal. Chem. 2015, 407, 6923-6938. [CrossRef] [PubMed]

75. Nowak, P.M.; Woźniakiewicz, M.; Gładysz, M.; Janus, M.; Kościelniak, P. Improving Repeatability of Capillary Electrophoresis—A Critical Comparison of Ten Different Capillary Inner Surfaces and Three Criteria of Peak Identification. Anal. Bioanal. Chem. 2017, 409, 4383-4393. [CrossRef] [PubMed]

76. Williams, B.A.; Vigh, G. Fast, Accurate Mobility Determination Method for Capillary Electrophoresis. Anal. Chem. 1996, 68, 1174-1180. [CrossRef] [PubMed] 